\title{
CAESAR CRISS-CROSSING THE RUBICON: A PALINDROMIC ACROSTIC IN LUCAN
}

$(B C$ 1.218-22)*

Lucan's account of Caesar crossing the Rubicon $(B C$ 1.213-22) is dense with metapoetic allusion. Although the river has been specified as a small stream at Caesar's arrival (ut uentum est parui Rubiconis ad undas, 1.185), it becomes swollen, tumidus, as soon as Caesar 'breaks the delay of war' and 'carries his standards in haste over the [now] swollen river' (inde moras soluit belli tumidumque per amnem | signa tulit propere, 1.204-5). This has been pinpointed both as a metapoetic signpost of Lucan's engagement with the anti-Callimachean swollen river of grandiose epic (Call. H. 2.108-9) at the outbreak of (his) Civil War, ${ }^{1}$ and as a programmatic statement that the whole $B C$ will set up a series of contrasts between Caesar's urgency in crossing boundaries and Lucan's narrative obstructions to or compliances with Caesar's progress. ${ }^{2}$ In fact, as Jamie Masters notes, "in spite of the "undoing of delay," the perfect "tulit" and the adverb "propere," Caesar has not crossed the river yet; or if he has, he must do it again, ${ }^{3}$ precisely at 1.213-22. Within this densely self-reflexive passage, Lucan inserts a palindromic acrostic which signals both the doubling

\footnotetext{
* I am indebted to John Henderson for believing in this fervently when my enthusiasm was tepid; to Danielle Frisby, whose handout brought my attention to it; to Emily Gowers, Alessandro Schiesaro and the anonymous referee of $C Q$ for their helpful suggestions.

${ }^{1}$ See C. McNelis, Statius' Thebaid and the Poetics of Civil War (Cambridge, 2007), 121, P. Chaudhuri, The War with God: Theomachy in Roman Imperial Poetry (Oxford, 2014), 213, and D. Frisby, 'Horses as the vehicle for metapoetic challenge: to what extent can we understand implicit self-referentiality at the appearance of a quadriga?', unpublished paper presented at the Metapoetics Workshop, King's College, Cambridge, 27th March 2014.

${ }^{2}$ J. Masters, Poetry and Civil War in Lucan's Bellum Civile (Cambridge, 1992), 2-3.

${ }^{3}$ Masters (n. 2), 2.
} 
of Caesar's action (or at least the poet's double mention of the action) and Lucan's poetic representation of Caesar taming the forces of nature. ${ }^{4}$

In the ecphrasis of the Rubicon, Lucan seems to linger on those atmospherical phenomena which could have made Caesar's enterprise more risky. He first describes the state of the dark-red Rubicon $^{5}$ in the summer, when it is made too hot by the burning season (cum feruida canduit aestas, 1.214), and then moves on to show how the winter season and three days of uninterrupted rain had actually provided the small stream with stronger and more dangerous waves (1.217-19), lines which may owe something to Livy's description of the river Druentia before Hannibal's Alpine crossing (Liv. 21.31.10-12), ${ }^{6}$ all the more so in view of Lucan's geographical incongruity of mentioning the Alps metonymically for 'mountains' at $1.219 .^{7}$

\footnotetext{
${ }^{4}$ The acrostic is listed among the 'Zufallsakrosticha' by I. Hilberg, 'Ist die Ilias Latina von einem Italicus verfasst oder einem Italicus gewidmet?', WS 21 (1899), 264-305, at 303. It is there placed next to another 'accidental acrostic': TEPES at Verg. A. 6.252-6, the description of Aeneas' sacrifice before entering the underworld, perhaps signalled, if deliberate, at A. 6.248 tepidum ... cruorem.

5 1.214 puniceus Rubicon, hinting at the Rubicon's etymology from ruber.

${ }^{6}$ See especially Liv. 21.31.12 et tum forte imbribus auctus ingentem transgredientibus tumultum fecit, with the assonance tum... tem... tumultum para-etymologically becoming Lucan's tumidum at $B C 1.204$.

${ }^{7}$ P. Roche, Lucan De Bello Ciuili Book I (Oxford, 2009), 219, following C.E. Haskins, M. Annaei Lucani Pharsalia (London, 1887), 15 and R.J. Getty, M. Annaei Lucani De Bello Ciuili Liber I (Cambridge, 1940), 57, does not find the mention of the Alps (as a metonymy rather than a geographical mistake) particularly noteworthy here. On the similarities between Hannibal and Lucan's Caesar, see F.M. Ahl, Lucan: An Introduction (Ithaca, 1976), 107-12.
} 
At the passage of Caesar's cavalry, however, the river seems to calm down and acquire a very moderate warmth:

fonte cadit modico paruisque inpellitur undis

puniceus Rubicon, cum feruida canduit aestas,

perque imas serpit ualles et Gallica certus

limes ab Ausoniis disterminat arua colonis.

tum uires praebebat hiemps atque auxerat undas

Tertia iam grauido pluuialis Cynthia cornu

Et madidis Euri resolutae flatibus Alpes.

Primus in obliquum sonipes opponitur amnem

Excepturus aquas; molli tum cetera rumpit

Turba uado faciles iam fracti fluminis undas.

(Luc. BC. 1.213-22)

Excepturus (221), in obliquum (220) and the polyptoton undis... undas... undas $(213,217,222)$, perhaps reminiscent of a now famous Virgilian acrostic in the Eclogues, ${ }^{8}$ may work as signals of the acrostic's presence. ${ }^{9}$ Additionally, the meteorological notation in line 218 may also be reminiscent of Virgil's famous signature acrostic at $G .1 .429-33$, in its turn a probable allusion to an acrostic in

${ }^{8}$ VNDIS, at Verg. E. 9.34-8, confirmed in line 39 ludus in undis: see A.A. Grishin, 'Ludus in undis: An Acrostic in Eclogue 9', HSPh 104 (2008), 237-40.

${ }^{9}$ Acrostics are normally 'announced' by certain key-words: see D. Feeney and D. Nelis, 'Two Virgilian Acrostics: Certissima Signa?', CQ 55 (2005), 644-6. 
Aratus' Phaenomena $783-87:{ }^{10}$ if so, the iunctura grauido... cornu (218) can be seen to pinpoint the fact that reverse reading is also at play, since the Virgilian acrostic was also reversed, and similarly signalled and framed by the horns of the moon (obscuro... cornu, G. 1.428; obtunsis... cornibus, 433). ${ }^{11}$ If one 'is ready to accept' (excepturus, 221) the acrostic, to be read 'obliquely' (in obliquum, 220) and 'palindromically' between the lines, then the verb TEPET would ironically indicate that the Rubicon has actually acquired quite a moderate warmth at the crossing of Caesar's sonipes: not too hot, as in line 214 , not too cold, as in lines $217-19 .{ }^{12}$ Secondly, the repetitive nature of the palindrome, to be read from top to bottom or - crossing back - from bottom to top, draws attention to Lucan's repetition of Caesar's crossing, and re-crossing, of the Rubicon.

In commenting on the scene, Roche interprets the danger posed to Caesar by the Rubicon in winter in line with Fantham's suggestion that 'nature in $B C$ may intermittently act with providential care for human safety'. ${ }^{13}$ This may initially be true, but at the same time Caesar's crossing of the

${ }^{10}$ The signature acrostic $P U-V E-M A-$ (Publius Vergilius Maro, to be read in reverse order from lines 433, 431 and 429) was discovered by E. Brown, Numeri Vergiliani: Studies in "Eclogues" and "Georgics" (Brussels, 1963), 102-5; on the possibility of a further 'window allusion' to an acrostic in Homer (Il. 24.1-5), see T. Somerville, 'Note on a Reversed Acrostic in Vergil Georgics 1.429-33', CPh 105 (2010), 202-9.

${ }^{11}$ I owe this intriguing suggestion to an anonymous reader.

${ }^{12}$ It could be argued that the verb tepesco may be preferred to tepeo in this context. However, it is difficult to imagine that Lucan would have produced an acrostic as long as tepescit, which would not have provided him, in any case, with a palindrome.

${ }^{13}$ Roche (n. 7), 218-19, referring to the question posed by E. Fantham, Lucan De Bello Ciuili Book II (Cambridge, 1992), 202: 'is there some sense of providential care for human safety?'. 
river, as with his cross of the Adriatic in the storm scene in Book $5,{ }^{14}$ suddenly turns the nature of Lucan's $B C$ into a docile creature, subjugated to his own will. Yet, this transformation of nature is only put in motion by Lucan's own wish to comply with Caesar's actions. Ultimately, it is the poet who retains the privilege of turning the Rubicon and its waters from docile to swollen and then docile again (paruis... undis, 213; auxerat undas, 217; faciles... undas, 222), from hot to freezing, as if the river was an anti-Callimachean second Euphrates, and then moderately warm (TEPET), like the waters of the 'speaking name' Pisciatello, if that is indeed the river with which we should identify the Rubicon. ${ }^{15}$ Thanks to Lucan's (mis)representation, Caesar can claim to have conquererd the stream (superato gurgite, 223) in the same 'Hannibalic' way that he had conquered the 'Alps' (superauerat Alpes, 182). Only now that the general's and the poet's intents have converged, can Caesar's war and Lucan's grandiose but Alexandrian epic properly begin.

\section{University of Glasgow}

E. GIUSTI

egiusti382@gmail.com

\footnotetext{
${ }^{14}$ See Caesar's rescue by a tenth wave at $B C$ 5.672-6, where Lucan seems to allude to the Virgilian model of Neptune in Aen. 1.145-7 in order to draw attention 'to the replacement of a divine agent by a "natural" phenomenon', as noted by M. Matthews, Caesar and the Storm: A Commentary on Lucan De Bello Ciuili, Book 5 lines 476-721 (Oxford and New York, 2008), 250.

${ }^{15}$ On the problematic identification, see P. Aebischer, 'Considerations sur le cours du Rubicon', MH 1 (1944), 258-69.
} 